\title{
Antitumor Drug Screening Assay
}

National Cancer Institute

\section{Source}

National Cancer Institute. Antitumor Drug Screening Assay. NCI Thesaurus. Code

C15229.

A technique used for assessment of the effectiveness of a potential antineoplastic agent. 